\title{
BIOECOLOGICAL DIAGNOSTICS OF OIL-CONTAMINATED SOIL REMEDIATED WITH POLYMERIC SORBENTS
}

\section{БИОЭКОЛОГИЧЕСКАЯ ДИАГНОСТИКА НЕФТЕЗАГРЯЗНЕННОГО ПОЧВОГРУНТА, ВОССТАНАВЛИВАЕМОГО ПОЛИМЕРНЫМИ СОРБЕНТАМИ}

\author{
VASILIEV, Sergey I. ${ }^{1 *}$; FOMINA, Natalya V. ${ }^{2}$; LAPUSHOVA, Lyubov A. ${ }^{3}$, FEDOTOVA, Arina \\ S. ${ }^{4}$; ZHURAVLEV, Dmitry N. ${ }^{5}$; \\ ${ }^{1}$ Siberian Federal University \\ ${ }^{2,4}$ Krasnoyarsk State Agrarian University \\ ${ }^{3}$ Krasnoyarsk Branch of Irkutsk State Transport University \\ ${ }^{5}$ NPF Ekosorb LLC \\ * Correspondence author \\ e-mail: s-vasilev1@yandex.ru
}

Received 22 June 2019; received in revised form 24 October 2019; accepted 30 October 2019

\section{RESUMO}

O impacto antropogênico nos ecossistemas ao redor dos campos de petróleo desenvolvidos causou problemas ambientais que afetaram todos os habitats dos organismos vivos. O método de sorção é considerado o mais eficiente e ambientalmente aceitável para a remoção de substâncias petrolíferas do solo. As vantagens dos sorventes poliméricos são a capacidade de remover vários contaminantes para praticamente qualquer concentração residual, ausência de contaminantes secundários e controlabilidade do processo de sorção. A atividade enzimática do solo é um indicador de seu estado ecológico e pode ser usada para avaliar o grau de contaminação, a intensidade da exposição e a eficiência da remediação. A análise enzimática é realizada através do estudo dos níveis de atividade das enzimas envolvidas em diferentes processos bioquímicos no solo. Isso pode fornecer informações mais confiáveis sobre mudanças no estado do solo. Nesta pesquisa, o diagnóstico bioecológico do solo contaminado com óleo foi realizado através do estudo das enzimas oxidativas (catalase) e hidrolíticas (urease, protease e invertase) antes e após a aplicação dos sorventes. Com base na comparação dos dados obtidos no estudo da atividade enzimática e celulolítica do solo com uma alteração na contagem microbiana total, nas propriedades morfológicas e biológicas dos microrganismos do solo e nas alterações hematológicas e bioquímicas nos modelos biológicos em relação às taxas de aplicação do sorvente, revelou uma correlação entre os índices de atividade biológica do solo, composição quantitativa e específica dos microrganismos. As reações químicas que ocorrem no solo, associadas ao metabolismo, decomposição e síntese de substâncias orgânicas, migração de compostos químicos, mobilização de nutrientes, são realizadas com a ajuda de enzimas. A alta sensibilidade, precisão, simplicidade relativa e fácil operação de métodos para determinar a atividade das enzimas do solo permitiram que fossem utilizados em estudos para avaliar a intensidade e a direção dos processos bioquímicos essenciais para a vida e fertilidade do solo. A atividade do solo serviu como um indicador integral do impacto ambiental.

Palavras-chave: solo, poluição, petróleo, sorventes poliméricos, enzima.

\section{ABSTRACT}

The anthropogenic impact on ecosystems around developed oil fields has caused environmental issues that affect all habitats of living organisms. The sorption method is considered the most efficient and environmentally acceptable for the removal of petroleum substances from the soil. The advantages of polymeric sorbents are the ability to remove various contaminants to almost any residual concentration, absence of secondary contaminants, and sorption process controllability. The enzymatic activity of soil is an indicator of its ecological state and it can be used to assess the degree of contamination, the intensity of exposure, and efficiency of remediation. The enzymic analysis is performed by studying the activity levels of enzymes involved 
in different biochemical processes in soil. This can give more reliable information on changes in the state of the soil. In this research, the bioecological diagnostics of oil-contaminated soil was carried out by studying oxidative enzyme (catalase) and hydrolytic enzymes (urease, protease, and invertase) before and after application of sorbents. Based on a comparison of data obtained in study of enzyme and cellulolytic activity of the soil with a change in the total microbial count, morphological and biological properties of soil microorganisms and hematological, biochemical changes in biological models with regard to application rates of sorbent, it was revealed a correlation between the indices of biological activity of the soil, quantitative and specific composition of microorganisms. Chemical reactions occurring in the soil, associated with metabolism, decomposition, and synthesis of organic substances, migration of chemical compounds, mobilization of nutrients, are carried out with the help of enzymes. High sensitivity, accuracy, relative simplicity and easy operation of methods for determining the activity of soil enzymes allowed them to be used in studies in assessing the intensity and direction of biochemical processes that are essential for soil life and fertility. The activity of soil served an integral indicator of the environmental impact.

Keywords: soil, pollution, petroleum, polymeric sorbents, enzyme.

\section{АННОТАЦИЯ}

Увеличение техногенного воздействия на экосистемы в районах освоения нефтяных месторождений вызвало ряд экологических проблем, охватывающих все среды обитания живых организмов и растений. Сорбционный метод очистки почвы и грунта от нефтепродуктов является наиболее эфффективным и экологически приемлемым способом. Преимуществом данного метода является возможность удаления загрязнений чрезвычайно широкой природы практически до любой остаточной концентрации, а также отсутствие вторичных загрязнений и управляемость процессом. Ферментативная активность почвы является показателем ее экологического состояния, поэтому может применяться для оценки как степени ее загрязнения, интенсивности воздействия и эффективности ремедиации. Ферментативный анализ необходимо проводить изучая уровни активности ферментов, участвующих в разных биохимических процессах в почве, что позволит получить более достоверную информацию об изменении ее состояния. Биоэкологическая диагностика нефтезагрязненной почвы и грунта в данной работе проводилась при изучении окислительного фрермента (каталаза) и гидролитических (уреаза, протеаза и инвертаза) до и после применения сорбентов. На основе сопоставления данных, полученных при изучении ферментативной и целлюлозолитической активности почвы с изменением общего микробного числа, морфо-биологических свойств микроорганизмов почвы и гематологических, биохимических изменений биологических моделей с учетом дозы внесения сорбента, выявлены корреляции между показателями биологической активности почвы, количественным и видовым составом микроорганизмов. Химические реакции, протекающие в почве, связанные с обменом веществ, разложением и синтезом органических веществ, миграцией химических соединений, мобилизацией питательных элементов и т.д., осуществляются с помощью фрерментов. Высокая чувствительность, точность, относительная простота и нетрудоемкость методов определения активности почвенных ферментов позволили использовать их в исследованиях при оценке интенсивности и направленности важнейших для жизни и плодородия почвы биохимических процессов. В данной работе активность почвенных ферментов принята как интегральный показатель воздействия факторов среды.

Ключевые слова: почвогрунт, загрязнение, нефрть, полимерные сорбенты, фрерменты.

\section{INTRODUCTION}

When studying the mechanism of oilcontaminated soil remediation with sorbents, a researcher should pay equal attention to the initial indicators, the analysis of processes occurring in petroleum substances in the soil, and the principles of sorption of the introduced pollutants by the sorbents. There are dozens of sorbent brands, both organic and polymer-based, that are used in oil spill response operations (Vasiliev and Melkozerov, 2011; Aznauryan, 2009).
The soil cover diagnostics with biochemical methods, in particular, with the help of enzyme indicators, has now been proven highly efficient. The enzymatic activity of soil was studied for different objects and, regardless of the aim of the research, this indicator is always considered as an integral expression of the action of environmental factors and interdependent processes occurring in the soil (Aznauryan, 2009; Dolgova, 1975; Kolesnikov et al., 2007; Kireeva et al., 2001; Fomina, 2013; Novoselova, 2004; Khaziyev and Fatkhiyev, 1981; Khaziyev et al., 1988; Schemelinina et al., 2007; Kireeva et al., 
1998). The influence of petroleum substances on soil enzymes includes direct impact, such as inhibiting, destroying or activating enzymes, and indirect impacts, such as changing the soil enzyme pool as a result of inhibiting the growth of soil mesofauna and plants. Enzymatic activity in oil-contaminated soils during remediation can help validate the effect of remediation on the properties of disturbed soils. Therefore, enzymatic activity, associated with the transformation of compounds of the main biogenic elements, is a complex representative indicator (Fomina, 2013). At the same time, the sorption mechanism in fertile soil remediation after oil spills needs to be studied further (Vasilyev et al., 2015).

\section{MATERIALS AND METHODS}

The subject of the study was an oilcontaminated mixture of soil and peat, with $\mathrm{pH}=$ $7.2, \mathrm{C}_{\text {org }}=18.9 \%$, and $\mathrm{N}=1.07 \%$. To simulate the contamination, oil from the Surgut deposit was introduced in concentrations of $6 \mathrm{~g}$ per $1 \mathrm{~kg}$ of soil (low) and $60 \mathrm{~g}$ per $1 \mathrm{~kg}$ of soil (high). Polymeric sorbents Unisorb-M, Unisorb-bio, and Unisorb-Ferro (Melkozerov et al., 2019; Zhuravlev et al., 2006) were used to remediate the soil. These sorbents are produced by the scientific and production organization LLP "Ekosorb", Krasnoyarsk Russia, there is a positive experience of their usage in the elimination of industrial accidents both in oil fields and in the liquidation of the accident at the Sayano-Shushenskaya hydroelectric station.

Ten soil samples were collected, including a control sample with no oil or sorbent introduced, a sample with oil, a sample with oil and Unisorb$\mathrm{M}$, a sample with oil and Unisorb-bio, and a sample with oil and Unisorb-Ferro (Melkozerov et al., 2014, 2017). The soil was sampled according to GOST 17.4.3.01-83 Nature protection. Soils. General requirements for sampling. The laboratory and analytical studies were performed using generally accepted methods in soil science and biology (Kazeev et al., 2003; Khaziyev, 2005). Catalase determination was carried out according to the Johnson and Temple (1964) method by titration with $0.1 \mathrm{n} \mathrm{KMnO}_{4}$ solution, the activity was expressed in $\mathrm{ml}$ of $0.1 \mathrm{n} \mathrm{KMnO}_{4} / \mathrm{g}$ dry soil for 20 minutes. The protease activity was determined by the method of Hoffmann and Teicher (1957) at a wavelength of $650 \mathrm{~nm}$ and expressed in $\mathrm{mg}$ of amine nitrogen $/ 10 \mathrm{~g}$ of soil over 20 hours. Urease activity was established by the method of Scherbakova (1983) by colorimetrication at a wavelength of $400 \mathrm{~nm}$ and expressed in $\mathrm{mg}$ of ammonium nitrogen $/ 10 \mathrm{~g}$ of dry soil for 4 hours. The invertase activity was studied by the method of colorimetric according to Hoffmann and Pallauf (1965) at a wavelength of $578 \mathrm{~nm}$ and expressed in $\mathrm{mg}$ of glucose/g of dry soil for 24 hours. All indicators of soil enzymatic activity were recalculated, taking into account soil moisture content per $1 \mathrm{~g}$ of soil.

In this research, the indicators of enzymatic activity are used as diagnostic criteria for validating the environmental safety and performance of sorbents, introduced to localize the oil contamination of soil (Vinogradova et al., 2015; Prudnikova et al., 2017). Redox enzymes have always received much attention because of their significant role in soil-forming processes (Pakharkova et al., 2015; Volova et al., 2017). The activity of this group of enzymes indicates the intensity of oxidation and the humification of organic substances.

\section{RESULTS AND DISCUSSION}

Earlier, it was established that the activity of soil enzymes is a sensitive indicator of the biological state of the soil (Aznauryan, 2009; Dolgova, 1975).

The catalase activity of contaminated soil varied depending on the concentration of oil. The high concentration reduced the activity to 0.35 $0.1 \mathrm{n} \mathrm{KMnO}_{4} \mathrm{ml}$ per $1 \mathrm{~g}$ of soil in 20 minutes, while the low concentration increased it to 0.43 $0.1 \mathrm{n} \mathrm{KMnO} \mathrm{ml}_{4}$ per $1 \mathrm{~g}$ of soil in 20 minutes. The catalase activity of the uncontaminated control sample was $0.37-0.390 .1 \mathrm{n} \mathrm{KMnO} 4 \mathrm{ml}$ per $1 \mathrm{~g}$ of soil in 20 minutes on average (Figure 1). The sorbents increased the catalase activity in the first and second cases, and in case of high contamination, the catalytic activity indicators were similar to those of the control sample (Figure 1).

In case of low contamination, the catalase activity increased to $0.42,0.44$, and $0.450 .1 \mathrm{n}$ $\mathrm{KMnO}_{4} \mathrm{ml}$ per $1 \mathrm{~g}$ of soil in 20 minutes with applied sorbents Unisorb-Ferro, Unisorb-M, and Unisorb-bio, respectively. There was a clear stimulation of catalase activity, especially with Unisorb-bio that contains a complex of hydrocarbon-oxidizing microorganisms.

The proteolytic activity of the uncontaminated control sample was 0.70-0.71 $\mathrm{mg}$ of amine nitrogen per $1 \mathrm{~g}$ of soil in 20 hours, while the high contamination gave a 1.5-time decrease in the activity and applied sorbent Unisorb-M reduced it by half to $0.35 \mathrm{mg}$ of amino nitrogen per $1 \mathrm{~g}$ of soil in 20 hours (Figure 2). On the contrary, sorbent Unisorb-bio-enhanced the 
proteolytic activity to $1.05 \mathrm{mg}$, which can be explained by its composition (microorganisms).

Having considered the indicators of proteolytic activity in contaminated soil in low concentration $(6 \mathrm{mg} / \mathrm{kg})$, it was found that in this concentration, oil has a stimulating effect on proteolysis $(0.79 \mathrm{mg})$. With Unisorb-M and Unisorb-bio, it was 0.90 and $0.96 \mathrm{mg}$, respectively. It should be noted that the highest indicators of this enzyme were also observed in the case of high contamination in the experiment with Unisorb-bio (Figure 2).

Sorbent Unisorb-Ferro reduced the proteolytic activity in both cases, yielding 0.31 and $0.53 \mathrm{mg}$ of amine nitrogen per $1 \mathrm{~g}$ of soil in 20 hours, thus approaching the activity values of the uncontaminated soil sample in case of high contamination.

Since urease participates in nitrogen metabolism, the study of its activity is absolutely necessary for diagnostics of contaminated soil. The initial urease activity of uncontaminated soil was $0.63 \mathrm{mg}$ of ammonium nitrogen per $1 \mathrm{~g}$ of soil in 4 hours. The introduction of oil at low concentration resulted in an increase in the urease activity to $0.93 \mathrm{mg}$ of ammonium nitrogen per $1 \mathrm{~g}$ of soil in 4 hours. In the samples with sorbents, the urease activity also increased and did not vary significantly; it was $0.96-1.05 \mathrm{mg}$ of ammonium nitrogen per $1 \mathrm{~g}$ of soil in 4 hours (Figure 3).

In the samples with high contamination, the urease activity decreased from $0.63 \mathrm{mg}$ (in the control sample) to $0.46 \mathrm{mg}$ of ammonium nitrogen per $1 \mathrm{~g}$ of soil in 4 hours, and in the samples with Unisorb-M and Unisorb-Ferro, to 0.39 and $0.43 \mathrm{mg}$ of ammonium nitrogen per $1 \mathrm{~g}$ of soils in 4 hours, respectively. A notable stimulation of urease activity was observed when using Unisorb-bio, containing germ cultures that affect the nitrogen metabolism in oilcontaminated soil.

Having analyzed the data on the invertase activity, it was found that in case of low contamination, its activity doubles on average. The sorbents also increased the invertase activity from medium $14.3 \mathrm{mg}$ of glucose per $1 \mathrm{~g}$ of soil in 24 hours to enriched $32.9-36.9 \mathrm{mg}$ of glucose per $1 \mathrm{~g}$ of soil in 24 hours (Figure 4) on Zvyagintsev's scale (1978).

A high level of soil contamination reliably reduced the invertase activity from $14.4 \mathrm{mg}$ to $13.5 \mathrm{mg}$ of glucose per $\mathrm{g}$ of soil in 24 hours, and with sorbents Unisorb-M and Unisorb-bio, to 12.9 and $13.6 \mathrm{mg}$ of glucose per $\mathrm{g}$ of soil in 24 hours, respectively. It should be noted that at this level of contamination, only Unisorb-Ferro enhanced the invertase activity, showing the remediation performance of $18.9 \mathrm{mg}$ of glucose per $1 \mathrm{~g}$ of soil in 24 hours.

The comparative study of enzyme activity was carried out to validate the 'unmarred' effect of sorbents on uncontaminated soil (Table 1). It was determined that the catalase activity does not differ from that of the control sample, while the urease activity, on the contrary, decreases by half, except for the samples with sorbent Unisorbbio.

The protease activity decreases insignificantly; at that, and the smallest decrease was observed in the samples with Unisorb-bio, most likely due to sorption (Table 1). The invertase activity after the application of the studied sorbents decreased insignificantly in the samples with Unisorb-M and Unisorb-bio, while Unisorb-Ferro did not significantly change its activity as compared to the control sample.

The enzymatic activity of oil-contaminated soil validated the performance of the studied sorbents. It can be observed in the increase in the enzyme activity in case of low contamination and the return of indicators to the control values in case of high contamination. The only exceptions are enzymes involved in nitrogen metabolism: significant contamination increased the activity only in samples with Unisorb-bio due to the presence of carbohydrate-oxidizing microorganisms.

\section{CONCLUSION}

When introduced into uncontaminated soil, sorbents Unisorb-M and Unisorb-bio yield an insignificant decrease in the invertase activity, while Unisorb-Ferro does not reduce the invertase activity as compared to the control sample.

The increase in the activity of soil enzymes after the introduction of Unipolymer polymeric sorbents at minimal contamination and the return to the control values at maximum contamination confirm the effective performance of the studied sorbents for remediation of oilcontaminated soil.

The application of the Unisorb series sorbents to the oil-contaminated soil with a low level of contamination ( $6 \mathrm{~g}$ of oil per $1 \mathrm{~kg}$ of soil) doubles the invertase activity.

At a higher level of contamination $(60 \mathrm{~g}$ of oil per $1 \mathrm{~kg}$ of soil), the urease activity decreases from $0.63 \mathrm{mg}$ as in the control sample to $0.46 \mathrm{mg}$ of ammonium nitrogen per $1 \mathrm{~g}$ of soil in 4 hours.

The application of sorbents Unisorb-M and Unisorb-Ferro at high contamination reduces 
the urease activity to 0.39 and $0.43 \mathrm{mg}$ per $1 \mathrm{~g}$ of soil, respectively, while sorbent Unisorb-bio, containing germ cultures, reliably stimulates the urease activity and increases the nitrogen metabolism in oil-contaminated soil.

At the high level of contamination, sorbent Unisorb-Ferro reduces the proteolytic activity to 0.31 and $0.53 \mathrm{mg}$ of amine nitrogen per $1 \mathrm{~g}$ of soil in 20 hours, thus approaching the proteolytic activity of uncontaminated soil.

The performance of the studied sorbents can be validated only in comparison to the performance in an uncontaminated soil sample. It was determined that all the studied sorbents did not significantly change the activity of catalase and invertase as compared to the control sample. However, they can reduce the activity of urease and protease, probably by reducing the activity of microorganisms in the soil.

The materials of this article can be useful for EHS professionals and students who study the environment of the northern petroleum provinces of Russia.

\section{REFERENCES}

1. Aznauryan, D. K. Izmeneniye ekologobiologicheskikh svoystv pochv Yuga Rossii pri zagryaznenii neftyu [Changes in ecological and biological properties of soils in the South of Russia due to oil contamination]. PhD Dissertation, Southern Federal University, Rostov-onDon, 2009. (in Russian).

2. Dolgova, L. G. Biokhimicheskaya aktivnost pochvy pri zagryaznenii [Biochemical activity of soil at contamination]. Pochvovedeniye [Soil Science], 1975, 4, 113-118 (in Russian).

3. Fomina, N. V. Izmeneniye biogennykh svoystv pochvy pod vliyaniyem tekhnogennogo zagryazneniya [Changes in soil biogenic properties under the influence of technogenic pollution]. Saarbrucken: Lap Lambert Academic Publishing, 2013.

4. GOST 17.4.3.01-83. Nature protection. Soils. General requirements for sampling, $2008 . \quad$ Available at: http://docs.cntd.ru/document/1200012800 (in Russian).

5. Kazeev, K. Sh., Kolesnikov, S. I., Valkov, V. F. (2003) Biologicheskaya diagnostika i indikatsiya pochv: metodologiya i metody issledovaniy [Biological diagnostics and indication of soil: Methodology and methods of research]. Rostov-on-Don:
Rostov State University, 2003. (in Russian).

6. Khaziyev, F. Kh. Metody pochvennoy enzimologii [Methods of soil enzymology]. Moscow: Nauka, 2005. (in Russian).

7. Khaziyev, F. Kh., Fatkhiyev, F. F. Izmeneniye biokhimicheskikh protsessov $\checkmark$ pochvakh pri neftyanom zagryaznenii i aktivatsiya razlozheniya nefti [Changes in biochemical processes in soils under oil contamination and activation of oil decomposition]. Agrokhimiya [Agrochemistry], 1981, 10, 102-111. (in Russian).

8. Khaziyev, F. Kh., Tishkina, E. I., Kireeva, N. A. Vliyaniye nefteproduktov na biologicheskuyu aktivnost pochv [Effect of petroleum products on soil biological activity]. Biologicheskiye nauki [Biological Sciences], 1988, 10, 93-99. (in Russian).

9. Kireeva, N. A., Novoselova, E. I., Khaziyev F. Kh. Carbohydrase activity in oil-contaminated soils. Eurasian Soil Science, 1998, 31(12), 1314-1318.

10. Kireeva, N. A., Vodopyanov, V. V., Novoselova, E. I., Onegova, T. S., Zhdanova, N. V. Mikrobiologicheskaya rekultivatsiya neftezagryaznennykh pochv [Microbiological remediation of oilcontaminated soils]. Moscow: VNIIOENG, 2001. (in Russian).

11. Kolesnikov, S. I., Tatosyan, M. L., Aznauryan, D. K. Izmeneniye fermentativnoy aktivnosti chernozema obyknovennogo pri zagryaznenii neftyu i nefteproduktami $v$ modelnykh eksperimentakh [Changes in enzymatic activity of black earth contaminated with petroleum and oil products in simulation experiments]. Doklady Rosselkhozakademii [Reports of the Russian Academy of Agricultural Sciences], 2007, 5, 32-34 (in Russian).

12. Melkozerov, V. M., Baryshev, I. E., Vasilyev, S. I., Matveykina, Ya. V., Fedotova, A. S. Features of the development of native microflora of oilcontaminated soils under sorption effects. Geology and petroleum potential of the West Siberian megabasin (experience, innovation). Bulletin of Tyumen Industrial University, 2014, 2, 191-196.

13. Melkozerov, V. M., Vasiliev, S. I., Velp A. Ya., Krylyshkin, R. N. Effektivnaya likvidatsiya avariynykh razlivov nefti i nefteproduktov $s$ primeneniyem sovremennykh tekhnologiy i polimernykh 
sorbentov [Efficient elimination of oil and oil product spills using modern technologies and polymeric sorbents]. Sistemy. Metody. Tekhnologii [Systems. Methods Technology], 2010, 3, 115-123. (in Russian).

14. Melkozerov, V. M., Vasilyev, S. I., Zhuravlev, D. N., Lapushova, L. A., Fedotova, A. S. Investigation of the characteristics of the modified sorbents of the Unipolymer and Unisorb series. Environmental protection in the oil and gas complex, Moscow, VNIONG, 2017, 3, 13-17.

15. Melkozerov, V. M., Zhuravlev, D. N., Sharipov, I. A., Vildanov, A. A., Vasilyev, S. I. The study of the properties of polymeric sorbents of various modifications used to eliminate oil spills in the water areas of the Arctic zone. Environmental protection in the oil and gas complex, Moscow, VNIONG, 2019, 1 , 49-55.

16. Novoselova, E. I. Strukturnofunktsionalnaya transformatsiya biogeotsenoza pri neftyanom zagryaznenii i puti yego vosstanovleniya [Structural and functional transformation of biogeocenosis under oil contamination and ways to remediate it]. Ufa: Bashkir State University Pub, 2004. (in Russian).

17. Pakharkova, N. V., Prudnikova, S. V., Gekk, A. S., Larkova, A. N., Korosteleva, N. S. Optimization of plant selection for the bioremediation of soils polluted by oil and oil products in the conditions of Southern Siberia. Bulletin of Krasnoyarsk State Agrarian University, 2015, 8, 28-33.

18. Rudnikova, S. V., Vinogradova, O. N., Trusova, M. Y. Specific character of bacterial biodegradation of polyhydroxyalkanoates. Doklady Biochemistry and Biophysics, 2017, 473(1), 94-97.

19. Schemelinina, T. N., Novoselova, E. I., Kireeva, N. A., Markarova, M. Yu. Diagnostirovaniye stepeni zagryaznennosti pochv neftyu po pokazatelyam fermentativnoy aktivnosti [Diagnosing the degree of soil contamination with oil by enzymatic activity]. Vestnik of Orenburg State University, 2007, 75, 432-434. (in Russian)

20. Vasiliev, S. I., Melkozerov, V. M. Okhrana okruzhayushchey sredy i ratsionalnoye nedropolzovaniye pri razrabotke, ekspluatatsii neftyanykh mestorozhdeniy, transportirovke nefti i nefteproduktov [Environmental protection and rational subsoil use in the development and operation of oil fields and the transportation of petroleum and oil products]. Saarbrucken, Lap Lambert Academic Publishing, 2011.

21. Vasilyev, S. I., Miloserdov, E. E., Bulchayev, N. D. Environmental problems in the development and exploitation of oil and gas fields in Eastern Siberia. Mining industry, 2015, 3, 88.

22. Vinogradova O. N., Prudnikova S. V., Zobova N. V., Kolesnikova V. L. Microbiological degradation of poly-3hydroxybutyrate in samples of agrogentransformed soils. Journal of the Siberian Federal University. Biology, 2015, 8(2), 199-209.

23. Volova, T. G., Prudnikova, S. V., Vinogradova, O. N., Syrvacheva, D. A., Shishatskaya, E. I. Microbial Degradation of Polyhydroxyalkanoates with Different Chemical Compositions and Their Biodegradability. Microbial Ecology, 2017, 73(2), 353-367

24. Wang, H., Fischer, T., Wieprecht, W., Möller, D. A predictive method for crude oil volatile organic compounds emission from soil: Evaporation and diffusion behavior investigation of binary gas mixtures. Environmental Science and Pollution Research, 2015, 22(10), 77357743.

25. Zhuravlev, D. N., Vasiliev, S. I., Voskresensky, A. G., Lubinets, G. G., Parshenok, A. G. Composition for polymeric sorbent. Patent $2663743 \mathrm{MCP}$ B 01J 20/26 B 01J 20/24 (2006/01), Moscow, RF, Russian Federation, 2006.

26. Johnson, J. L.; Temple, K. L. Some variables affecting the measurement of 'catalase activity' in soil. Soil Science Society of America Proceedings, 1964, 28:, 207-209.

27. Hoffmann G., Teicher K. Enzyme systems of our arable soils. VII. Proteases. Z. PflErnähr Düng. Bodenk., 1957, 77, 243251.

28. Scherbakova T. A. Enzymatic activity of the soil and the transformation of organic matter. Minsk: Science and Technology, 1983.

29. Hoffmann, G., Pallauf, J. Advances in Enzymology and Related Areas of Molecular Biology, 1965. 
Table 1. Average activity of soil enzymes with the application of sorbents

\begin{tabular}{|c|c|c|c|c|}
\hline Experiment option & $\begin{array}{c}\text { Catalase, } \\
0.1 \mathrm{n} \mathrm{KMnO} \mathrm{KMn}_{4} \\
\mathrm{ml} \mathrm{per} 1 \mathrm{~g} \text { of } \\
\text { soil in } 20 \mathrm{~min}\end{array}$ & $\begin{array}{l}\text { Urease, mg of } \\
\text { ammonium } \\
\text { nitrogen per } 1 \\
\mathrm{~g} \text { of soil in } 4 \mathrm{~h}\end{array}$ & $\begin{array}{c}\text { Protease, } \\
\text { mg of amine } \\
\text { nitrogen per } 1 \mathrm{~g} \\
\text { of soil in } 20 \mathrm{~h}\end{array}$ & $\begin{array}{c}\text { Invertase, } \\
\text { mg of glucose } \\
\text { per } 1 \mathrm{~g} \text { of soil in } \\
24 \mathrm{~h}\end{array}$ \\
\hline $\begin{array}{l}\text { Control sample } \\
\text { (clean soil) }\end{array}$ & $0.38 \pm 0.02$ & $0.63 \pm 0.17$ & $0.70 \pm 0.27$ & $14.4 \pm 2.4$ \\
\hline Soil + Unisorb-M & $0.38 \pm 0.01$ & $0.30 \pm 0.10$ & $0.58 \pm 0.12$ & $13.5 \pm 2.1$ \\
\hline Soil + Unisorb-bio & $0.37 \pm 0.02$ & $0.48 \pm 0.12$ & $0.61 \pm 0.25$ & $13.2 \pm 2.0$ \\
\hline Soil + Unisorb-Ferro & $0.38 \pm 0.02$ & $0.37 \pm 0.02$ & $0.55 \pm 0.12$ & $14.0 \pm 2.2$ \\
\hline
\end{tabular}

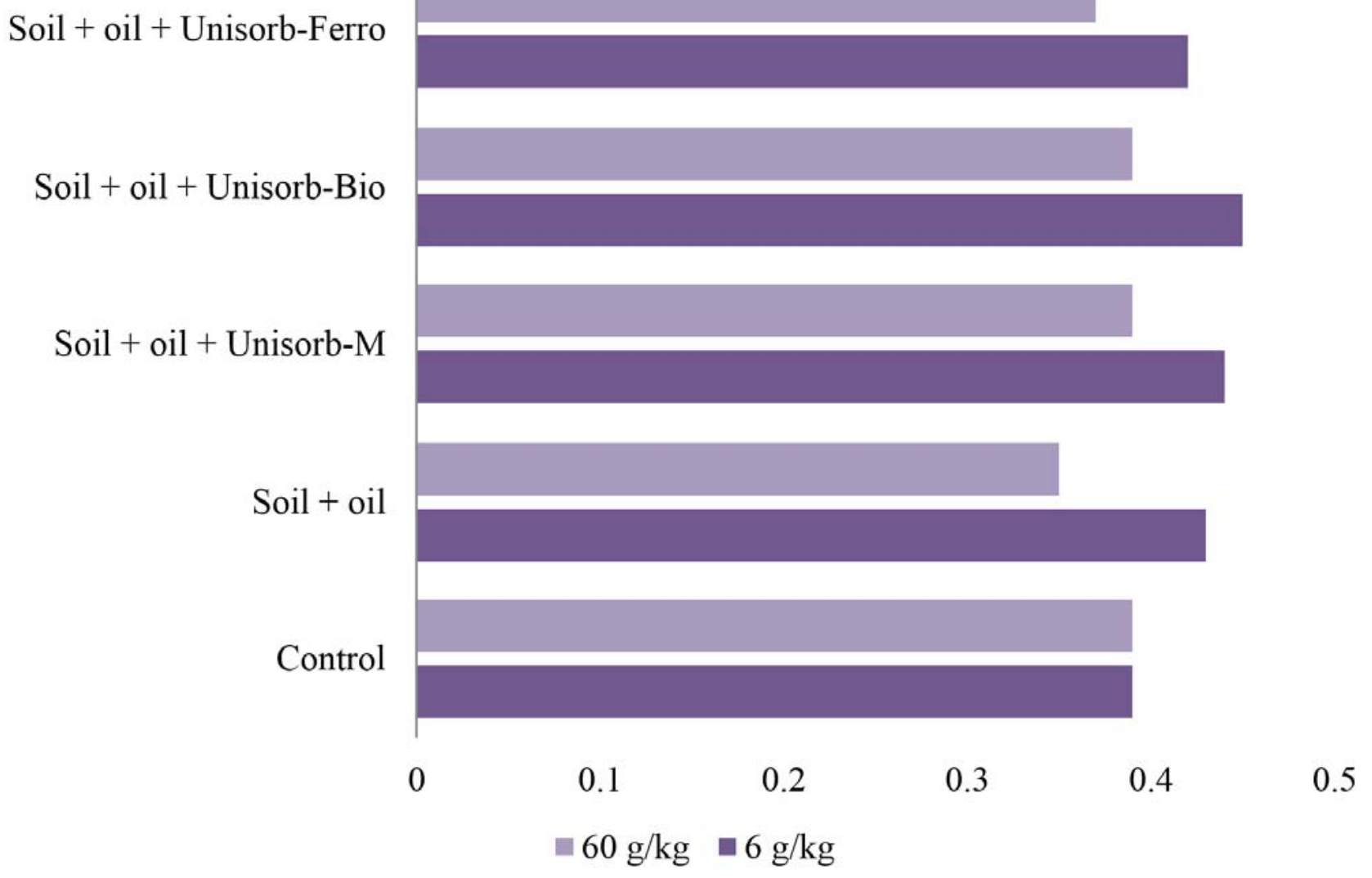

Figure 1. Catalase activity in oil-contaminated soil 


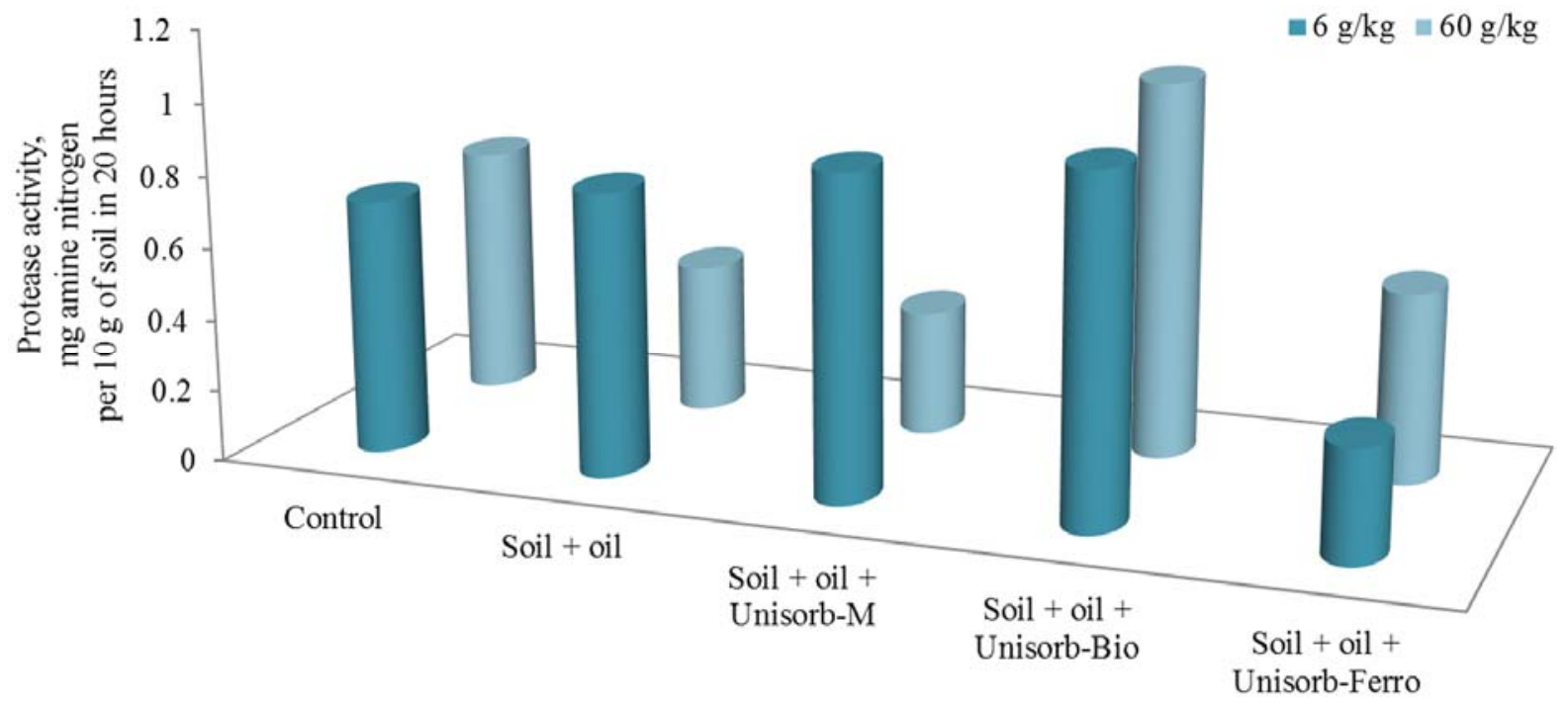

Figure 2. Protease activity in oil-contaminated soil

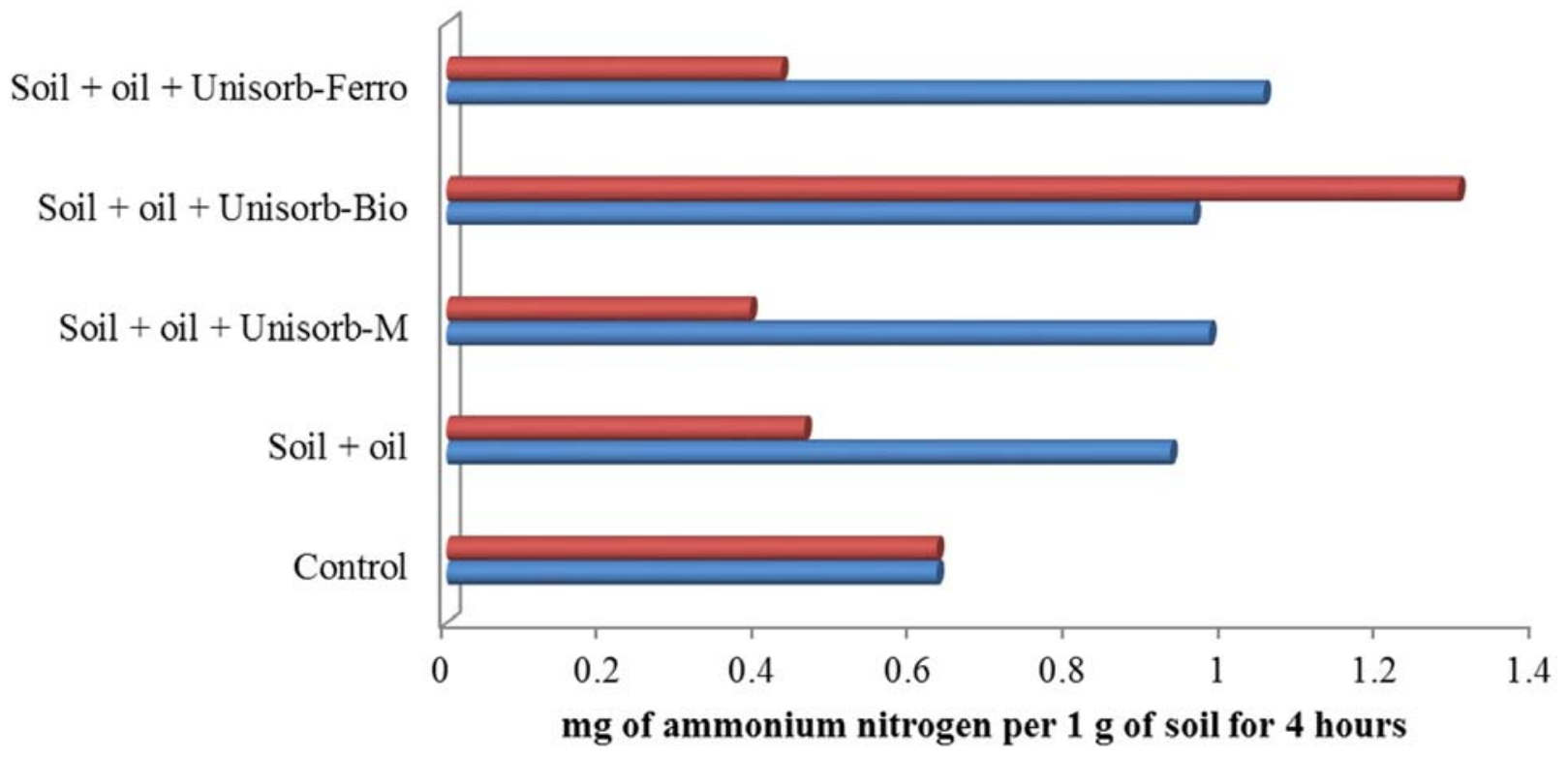

Figure 3. Urease activity in oil-contaminated soil 


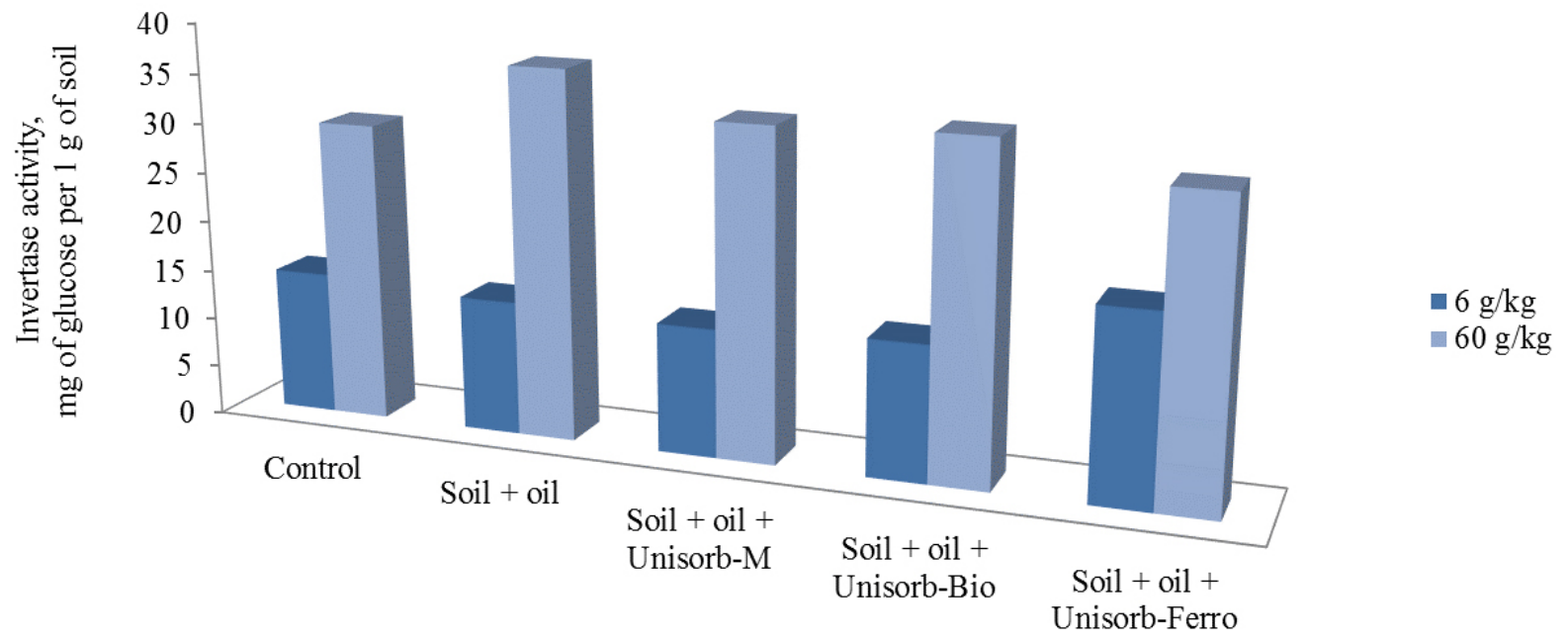

Figure 4. Invertase activity in oil-contaminated soil

Periódico Tchê Química. ISSN 2179-0302. (2019); vol.16 (n³3)

Downloaded from www.periodico.tchequimica.com

OPEN ACCESS. This article is licensed under a Creative Commons Attribution 4.0 (CC BY 4.0) International License, which permits use, sharing, adaptation, distribution, and reproduction in any medium or format, as long as you give appropriate credit to the original author(s) and the source, provide a link to the Creative Commons license, and indicate if changes were made. The images or other third-party material in this article are included in the article 's Creative Commons license unless indicated otherwise in a credit line to the material . If material is not included in the article's Creative Commons license and your intended use is not permitted by statutory regulation
or exceeds the permitted use, you will need to obtain permission directly from the copyright holder. To view a copy of this license, visit http://creativecommons. org/licenses/by/4.0/. 